\title{
共創活動の成果創出を促進する要因の検証 Verification of Factors Promoting Creation of Outcomes of Co-Creation Activities
}

\author{
堀田 竜士 \\ Ryoji Horita \\ 富士フイルムビジネスイノベーション株式会社 \\ FUJIFILM Business Innovation Corp. \\ ryoji.horita.wv@fujifilm.com \\ 伊藤 孝行 \\ 京都大学 大学院 情報学研究科社会情報学専攻 \\ Takayuki Ito \\ Graduate School of Informatics, Kyoto University. \\ ito@i.kyoto-u.ac.jp
}

Keywords: co-creation, JSAI-CCI, academic workshop, social media

Summary

The purpose of this research is to verify the factors that promote creation of new outcomes through co-creation activities. The following three hypotheses were made; 1 . The higher degree of achievements of aims set by the academic workshop, the more user activity on social media and the number of outcomes through co-creation projects created, 2 . The more positive feedback on user activities on social media, the more user activity increases, 3 . As the number of user activities on social media increases, the number of outcomes generated through co-creation projects increases.

The target of this research was Special Interest Group on Crowd Co-Creation Intelligence at The Japanese Society for Artificial Intelligence. The feature of this group is to support creation of co-creation project and to promote activities by combining the academic workshop and social media. The following four data were analyzed; (a) Result of questionnaire conducted after academic workshops, (b) Log data of social media, (c) The number of new outcomes generated by co-creation activities. Each data of (a) to (c) were aggregated for each co-creation project. Spearman's rank correlation coefficient was calculated. A causal relationship model that affected the number of outcomes was constructed by path analysis using items which correlation was significant.

As results, the following four findings were obtained; 1 . Promoting the sharing of participants' activities and interests in the academic workshop activate the number of discussion on social media and increase the number of outcomes generated through co-creation projects, 2 . Increasing the number of cheer for co-creation projects contributes to increasing the number of comments on social media and outcome of co-creation projects, 3. Supporting increase the number of comments on social media increases the number of outcomes generated by co-creation projects, 4 . The causal relationship model that affects the number of outcomes had a certain validity.

\section{1.はじめに}

人口減少や少子高齢化, 過疎化等によって生じる様々 な課題への対応として, 日本全国で地方創生が求められ ている. 伊藤[伊藤 17] は, 既存の地方創生活動の課題を 解決する「ソーシャルメディアによる市民共創知支援モ デル」を提案した．多地域移動型の研究会とソーシャル メディアを組み合わせ，地域課題解決を目的とした共創 を支援する社会システムの全体像を提示した。

上記の 2 つの要素のうち, 多地域移動型の研究会は. (1)開催地域に関する学習, (2)発表・対話, (3)共創プロジ エクトの創出, (4)共創活動の実践, という研究者と市民 の共創の 4 ステップを反映し設計された[堀田 19a]. 市 民共創知研究会における活動を対象として(1)から(3)のス テップの有效性が検証された結果, 各プログラムの狙い
が達成されたことが示された.

もう1つの要素であるソーシャルメディアは, (4)共創 活動の実践の実現を目指して構築された[堀田 19b]. 市 民共創知研究会で創出された共創プロジェクトの活動を 対象に有効性が検証された結果，活動の継続・共有が行 われている実態が明らかになった。更に，継続に寄与す るソーシャルメディア上のユーザ行動と, それらのユー ザ行動を促進する機能が示された。

以上の研究では，共創プロジェクトの創出と共創活動 の継続に寄与する要因は示されたものの, 成果の創出を 促進する要因は明らかにされていない，地方創生におい ては, 活動が継続されるだけでなく, 地域課題解決を促 す新たな成果が創出されることが望ましい.

本研究の目的は, 共創活動を通じた新たな成果の創出 を促進する要因を検証することである．このことによっ て, 共創活動における成果創出のための人や人工知能に 
よる支援環境構築に寄与できると考える.

本論文の構成は以下の通りである．２章で関連研究を 示し, 本研究の位置づけを明らかにする. 3 章で既存研 究から導出される仮説と, 仮説検証の方法について述心 4 章で仮説検証の結果を示す. 5 章で仮説との整合性や 既存研究で示された結果との差異について考察し, 6 章 で本論文をまとめる.

\section{2. 関連研究}

共創は「背景の異なる人々が，共通の目標の達成や課 題の解決のために, 共に創造活動を実施すること」と定 義される[堀田 19a]. 共創に関する研究は様々な分野で 行われているが，本研究では市民を中心的なステークホ ルダーに据えた共創を扱う。代表的な活動には, Civic Tech, Living Lab, Future Center 等が存在する.

Civic Tech は，ICT に関する技術的な視点と土地勘を 有した市民が，自治体と共に中長期的に地域課題解決に 取り組む活動である[瀬戸 16]. 多数の実践事例が存在し, Civic Techによって生み出されたアプリケーションが地 域課題の解決に寄与した例も存在する[古崎 16].

Living Lab は, 実際の生活環境やコミュニティにおけ る体系的な共創手法, 統合的な調查, イノベーションプ ロセスに基づく, ユーザ中心のオープンイノベーション エコシステムと定義される[ENoLL 06]. 実生活環境を利 用して新たな製品・サービスのアイデア出しや仮説検証 を行う点が特徵的である[Bergvall-Kåreborn 09].

Future Center は, 未来の知的資本を生み出す場であ る[野村 12]. 社会課題解決や組織風土改革を目的として, 対話, 未来志向, デザイン思考といった方法論を組み合 わせ, 企業, 自治体, 市民等の参加者の関係性構築, ア イデア創出，シナリオ形成を実施する.

これらの活動では, 主に対話ワークショップ(以下，対 話 WS と記す)によって共創プロジェクトの創出には成 功しているものの, 活動が持続しないという課題がある. Civic Tech では，非技術者の参加者を増やすための取り 組みが各地で行われているが，それらの多くは短期的な 活動に留まっており, 活動の発展性や継続性に課題を抱 えている[大西 17]. Living Labに関しては, 実践におけ る知見・ノウハウが体系的に整理されていない[赤坂 17]. Future Center に関しても，持続的に活動が行われてい る事例は少ない[宇賀田 17].

共創活動の持続化のために, 現在では主に(1)活動の主 催者による手厚い支援, (2)対話 WS 後の ICT の導入, の 2 つの方法が採用されている.

(1)に該当する研究には, 地域課題解決のためのアイデ ア創出から事業化計画の立案までを支援する研究[井上 16]や, 関係性構築, 地域課題解決のためのアイデア創出, 活動の具体化, 定着を支援するプロセスの研究[高橋 15] が存在する.これらの研究では, 活動の主催者による人
脈形成支援やノウハウ伝授等の手厚い支援が，活動の持 続化や成果の創出に寄与している. しかし, 多大な人的・ 時間的リソースが必要である，属人的なノウハウに依存 しているため他地域一の展開が困難である，等の課題が ある. 複数地域で共通の地域課題が発生する例も少なく ないため, 他地域への展開が容易な手法が求められる.

(2)に該当する研究は，(1)で発生する課題への対策と して行われた. 対話 WS 後に ICT を活用し，持続的な共 創活動の支援を試みた研究[涌井 15]では, ICT 上のコラ ボレーションは，テーマへの継続的な意識づけに効果的 であることが示唆された. ICT を活用したゲーミフィケ ーションによる行動支援プラットフォームを構築した研 究[根本 14]では, 対話 WS 後の活動が持続するゲームで は, 行動に対するフィードバックや他者行動の共有が有 効に機能していたことが示された. 共創プロジェクト活 動を支援するソーシャルメディアを構築した研究[堀田 19b]では，ソーシャルメディアが共創プロジェクトに関 する活動の継続と多様なユーザとの共有に寄与している ことが示された。

以上の研究では, 対話 WS 後の ICT の導入は, 活動 に対する継続的な意識づけや活動の継続に有効であるこ とが示された. しかし, 成果の創出に寄与する要因は明 らかになっていない. 成果の創出に寄与する要因が明ら かになれば，共創支援手法を具体的に検討できるように なると考えられる.

\section{3. 仮説と研究方法}

\section{$3 \cdot 1$ 仮説}

本研究では, 既存研究から導出した以下の 3 つの仮説 を検証する．これらの仮説を検証することで, 共創プロ ジェクトを生み出す対話 WS と, 対話 WS 後の持続的な 活動を支援する ICT を組み合わせた共創において, 対話 WS の狙いの達成度, ICT 上のユーザ行動, 新たな成果 の創出という3 つの要素の関係が明らかになると考える. なお, 達成度とは対話 WS による参加者同士の理解促進, 関係性構築，共創活動に対する動機づけ等の程度を，ユ ーザ行動とは ICT 上のユーザによる活動を, 成果とは共 創活動によって創出された新たなアウトプットを指す.

・【仮説 1】対話 WS の狙いの達成度が高いほど, ユーザ 行動数が増加する.

・【仮説 2】ユーザ行動に対するフィードバックが多いほ ど, ユーザ行動数が増加する.

・【仮説 3】ユーザ行動数が多いほど, 成果数が増加する.

【仮説 1】について, 涌井[涌井 15]は, ICT 上のコメ ントの障壁を下げる要因として, 対話 WS による「背景 と方向性の共有」と「関係の質の高まり」が存在するこ とを示した．対話 WS の機能が，ユーザ行動を促進する 可能性が示唆される。一方, 涌井が示した要素は 3 件の 
プロジェクト活動から抽出したものであり，他にもユー ザ行動に寄与する対話 WS の機能が存在すると考えられ る. 本研究では, 対話 WS の機能に対応した狙いの達成 度がユーザ行動に与える影響を検証する。

【仮説 2】について，根本[根本 14]は，ユーザ行動が 持続する要因として,「行動に対するフィードバック」,

「他者行動の共有」,「求められる行動と参加者の能力と の適合」を挙げた. 本研究では特に[根本 14]で分析・考 察の中心となっており，確度が高いと考えられる「行動 に対するフィードバック」に注目し，ユーザ行動に対す るフィードバックが他のユーザ行動に与える影響を分析 する.

【仮説 3】について, 堀田[堀田 19b]は, ユーザ行動と 創出される成果の関係について, (1)共創プロジェクトに 関する議論が行われるとコメント数が増加する，(2)議論 の中で実践すべきアイデアが出ると，アイデアが実践・ 報告され，進捗報告の数が増加する，(3)(1), (2)のサイク ルが何度か繰り返された結果, 成果が創出される, とい ったプロセスが存在するという仮説を提示した。 この仮 説が正しければ，コメントや進捗報告等のユーザ行動数 が増加するほど, 新たな成果数が増加すると推測される.

\section{2 研究対象}

研究対象として, 市民共創知研究会[伊藤 17](以下, 本 研究会と略す)を選択した. 本研究会の特徵は, 多地域移 動型の研究会とソーシャルメディアを組み合わせ，共創 プロジェクトの創出・推進・共有を行っていることであ る. 多地域移動型の研究会は, フィールドワーク（以下, FW と記す), 研究発表, 及び対話 WS を組み合わせたプ ログラムで構成されている，中でも，市民が抱える地域 課題と研究者が保有する技術をマッチングさせ，地域課 題の解決や新たな研究成果の創出を目的とした共創プロ ジェクトを生み出す上で，対話 WS が中心的な役割を果 たしている. 研究会後はソーシャルメディア上で共創プ ロジェクトの活動を推進し, 新たな成果を生むことを目 指す．対話WS を中心とした研究会による共創プロジェ クトの創出と, ソーシャルメディアによる ICT 上の活動 を通じて成果を創出する枠組みが, 本研究の対象として ふさわしいと考え, 本研究会を研究対象とした.

\section{3 分析対象}

分析対象のデータとして, a. 研究会後に実施されたア ンケートの回答, b.ソーシャルメディアのログデータ, c. 共創活動によって創出された新たな成果を抽出した．市 民共創知研究会はこれまで 5 回実施されているが，a か ら c の全てのデータが揃っている第 1 回研究会及び第 2 回研究会のデータを分析対象とした. 表 1 に, 各研究会 の概要を示す.

表 2 に, 各研究会で創出された共創プロジェクトを示 す. 表 2 に示したように, 第 1 回研究会では 5 個, 第 2

\section{表 1 研究会概要}

\begin{tabular}{|c|c|c|c|c|c|c|c|}
\hline \multirow[b]{2}{*}{ 研究会 } & \multirow[b]{2}{*}{ 日時 } & \multirow[b]{2}{*}{ 場所 } & \multicolumn{5}{|c|}{ 参加者数 } \\
\hline & & & 地域 & 大学 & $\begin{array}{l}\text { 企業 } \\
\text { NP0 }\end{array}$ & その他 & 計 \\
\hline 1 回 & $2016 / 11 / 25-27$ & 岩手県遠野市 & 23 & $\overline{11}$ & $\overline{116}$ & & \begin{tabular}{l|l}
3 & 59
\end{tabular} \\
\hline 第2 & $2017 / 6 / 30-7 / 2$ & 長崎県対馬市 & 12 & 2 & 9 & & $\begin{array}{l}4 \quad 54 \\
\end{array}$ \\
\hline
\end{tabular}

表 2 共創プロジェクト研究会概要

\begin{tabular}{|c|c|c|}
\hline \# & 研究会 & プロジェクト名 \\
\hline 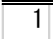 & & "スーパーアグリ構想 \\
\hline 2 & & みらい創りの仲間づくり \\
\hline 3 & 第1回 & 遠野らしい学びの場を創る \\
\hline 4 & & 共創のための舞台をつくる 〜次回研究会に向けて〜 \\
\hline 5 & & 新しい働き方をレシピ形式で集約する方法の提案 \\
\hline 6 & & AI x 対馬 : AIで日本史を書き換える！ \\
\hline 7 & & みんなでICTを楽しむ！ \\
\hline 8 & & 井戸端リテラシー向上委員会 \\
\hline 9 & & 学びとものづくり空間「TSUSHIMA DESIGN」設立 \\
\hline 10 & & ボウズレス釣り会員 \\
\hline 11 & 第2回 & 対馬しごと銀行 \\
\hline 12 & & 対馬感動プロジェクト \\
\hline 13 & & 団つけ餅投げ祭 \\
\hline 14 & & 第3回研究会「みらいらぼなごや」の共創 \\
\hline 15 & & 地方就活生の夢を乗せて。新幹線合説プロジェクト \\
\hline 16 & & カードゲームや辞書を使った遊びを広めたい \\
\hline
\end{tabular}

回研究会では 11 個の共創プロジェクトが登録された.こ れらのうち, 継続日数が 2 週間以下のプロジェクトは活 動の立ち上げが十分に行われなかった可能性があるため, 分析対象から外した. 同様に, 研究会幹事がオーナーを 務めたプロジェクトは，見本として挙げられたものやソ ーシャルメディア以外の活動がメインだったものが多か ったため, 分析対象から外した. 以上から, 表 2 のか ら9の 9 個の共創プロジェクトを分析対象とした.

a. 研究会後に実施されたアンケートの回答

アンケートの質問項目，回答方法，プログラムの狙い との対応を表 3 に示す. 堀田[堀田 19a]は, 市民と研究 者の共創を生み出す 4 ステップを設計した，研究会では (1)から(3)のステップ, ソーシャルメディアでは(4)のステ ップの実現を目指した．本アンケートの設問は，研究会 で実現を目指した(1)から(3)のステップの狙いに対応する よう事前に設計された。 (1)から(3)のステップの狙いを以 下に示す. (1)が FW や民泊等, (2)・ (3)が対話 WS で実現 を目指した狙いである.

(1)「開催地域に関する学習」の狙い: 開催地域の魅力 や課題を知る

(2)「発表・対話」の狙い: 他の参加者の活動や関心を 知る, 及び他の参加者と関係性を築く

(3) 共創プロジェクトの創出の狙い: 研究会後に共創活 動を行うための動機づけを行う 
これらの狙いを達成するための研究会プログラムを 設計した[堀田 19a]. (1)関しては, FW や民泊等を取り 入れた. FW では, 地域の専門家から地域の現状・課題 を共有してもらった：民泊ではホテルのような宿泊施設 ではなく，実際の民家に宿泊することを通じて，現地の 市民の生活の実態や抱える課題を把握することを目指し た. (2)に関しては, 一般的な研究発表と, 参加者の主体 的な議論を促進するホールシステム・アプローチ[香取 11]を中心とした対話を融合させた対話 WS を設計した. (3)に関しては, プロジェクト創出に適した Open Space Technology[オーエン 07]を応用した対話 WS を設計した. アンケートは, 各研究会終了後に研究会のメーリング リストに登録した参加者に送付された. 全体の回答率は, 第 1 回研究会が $68.8 \%$, 第 2 回研究会が $54.0 \%$ だった. 分析対象とした共創プロジェクトの参加者の回答率は, 第 1 回研究会が $87.5 \%$, 第 2 回研究会が $50.0 \%$ たた.

\section{表 3 アンケート項目}

\begin{tabular}{|c|c|c|c|}
\hline \# & 質問項目 & 回答方法 & $\begin{array}{l}\text { 狙いと } \\
\text { の対応 }\end{array}$ \\
\hline Q1 & $\begin{array}{l}\text { 研究会を通して, 地域の魅力や } \\
\text { 課題を知ることができました } \\
\text { か? }\end{array}$ & $\begin{array}{l}\text { 6段階のリッカート尺 } \\
\text { 度による評価 }\end{array}$ & (1) \\
\hline Q2 & $\begin{array}{l}\text { 研究会を通して, 他の参加者の } \\
\text { 活動や関心を知ることができま } \\
\text { したか? }\end{array}$ & $\begin{array}{l}\text { 6段階のリッカート尺 } \\
\text { 度による評価 }\end{array}$ & (2) \\
\hline Q3 & $\begin{array}{l}\text { 研究会を通して, 他の参加者と } \\
\text { 関係性を築くことができました } \\
\text { か? }\end{array}$ & $\begin{array}{l}\text { 6段階のリッカート尺 } \\
\text { 度による評価 }\end{array}$ & (2) \\
\hline Q4 & $\begin{array}{l}\text { 研究会を通して，共創のアイ } \\
\text { ディアを得ることができました } \\
\text { か？ }\end{array}$ & $\begin{array}{l}\text { 6段階のリッカート尺 } \\
\text { 度による評価 }\end{array}$ & (3) \\
\hline Q5 & $\begin{array}{l}\text { 今後, 他の参加者と共創活動を } \\
\text { 行いたいと思いますか? }\end{array}$ & $\begin{array}{l}\text { 6段階のリッカート尺 } \\
\text { 度による評価 }\end{array}$ & (3) \\
\hline Q6 & $\begin{array}{l}\text { 今後, 他の参加者と取り組みた } \\
\text { い共創プロジェクトはあります } \\
\text { か? }\end{array}$ & $\begin{array}{l}\text { 「1.ある」, 「2.な } \\
\text { い」の2択 }\end{array}$ & (3) \\
\hline Q7 & $\begin{array}{l}\text { 今後, 他の参加者と共創活動を } \\
\text { 行う予定はありますか? }\end{array}$ & $\begin{array}{l}\text { 「1.ある」，「2.現段 } \\
\text { 階で予定はない」， } \\
\text { 「3.ない」の3択 }\end{array}$ & (3) \\
\hline Q8 & $\begin{array}{l}\text { 市民共創知研究会の「共創の取 } \\
\text { り組みとしての可能性」をどの } \\
\text { 程度感じましたか? }\end{array}$ & $\begin{array}{l}\text { 6段階のリッカート尺 } \\
\text { 度による評価 }\end{array}$ & 全体 \\
\hline Q9 & $\begin{array}{l}\text { 次回研究会に参加したいと思い } \\
\text { ますか? }\end{array}$ & $\begin{array}{l}\text { 「1.はい」, 「2.いい } \\
\text { え」, 「3.どちらとも } \\
\text { いえない」の3択 }\end{array}$ & 全体 \\
\hline
\end{tabular}

\section{b. ソーシャルメディアのログデータ}

ログデータの種類を表 4 に示す. 各機能の詳細は別報 [堀田 19b]に記した. 表 4 のうち, 本研究で対象とした ユーザ行動は 1 から 8 である. 5.応援は共創プロジェク トに対する応援の意向を示す機能, 8.サポートはプロジ
エクトの推進のために必要な支援を全ユーザに求めるこ とができる機能である. 第 1 回研究会と第 2 回研究会の 双方で利用実績があり，共創活動の促進と関連があると 考えられる 4 から 7 のデータを分析対象とした. 1 はソ ーシャルメディアにアクセスした際に付随的に取得され るデータであるため, 分析対象から外した，2，3 はユー ザ登録，およびプロジェクト作成時に 1 回のみ発生する ユーザ行動であり，共創活動の促進との関連は小さいこ とが予想されたため, 分析対象から除外した. 8 は第 2 回 研究会で利用実績がなかったため, 分析対象から外した. 2016 年 11 月 27 日から 2018 年 3 月 14 日までのログデー タを分析に用いた。

\begin{tabular}{|c|c|c|}
\hline$\#$ & 種類 & 内容 \\
\hline 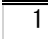 & "アアクセス & 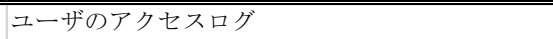 \\
\hline 2 & ユーザ & ユーザ登録されたユーザの情報 \\
\hline 3 & プロジェクト & 作成されたプロジェクトの情報 \\
\hline 4 & 参加 & $\begin{array}{l}\text { 参加機能を用いて行われたプロジェクトへ参加し } \\
\text { たユーザの情報 }\end{array}$ \\
\hline 5 & 応援 & $\begin{array}{l}\text { 応援機能を用いて行われたプロジェクトに対する } \\
\text { 応援に関する情報 }\end{array}$ \\
\hline 6 & コメント & 議論機能を用いて行われたコメントに関する情報 \\
\hline 7 & 進捗報告 & $\begin{array}{l}\text { 進捗報告機能を用いて行われた活動の進捗に関す } \\
\text { る情報 }\end{array}$ \\
\hline 8 & サポート & $\begin{array}{l}\text { サポート機能を用いて行われたプロジェクトに対 } \\
\text { する支援に関する情報 }\end{array}$ \\
\hline 9 & ポイント & $\begin{array}{l}\text { インセンティブ機能を用いて付与されたポイント } \\
\text { に関する情報 }\end{array}$ \\
\hline 10 & コンテスト & $\begin{array}{l}\text { コンテスト機能を用いて投稿されたアイデア，ア } \\
\text { イデアに対する投票に関する情報 }\end{array}$ \\
\hline
\end{tabular}

表 5 にコメントのログデータの例を示す．各ログには id が付与され(id), コメント内容(body), 投稿したユーザ (user_id), 投稿されたプロジェクト(project_id), 投稿日時 (create_at), 更新日時(update_at)が記録される. 他のコメ ントに対する返信の場合は, 親のコメントの id も記録さ れる(parent_id). 画像が付与された場合は, 画像のファイ ル名が記録される(image).

\section{表 5 ログデータの例（コメント）}

\begin{tabular}{|c|c|c|c|c|c|c|c|}
\hline \multirow{2}{*}{ id } & \multirow{2}{*}{ body } & \multicolumn{2}{|c|}{ user_project } & \multirow{2}{*}{$\begin{array}{l}\text { parent } \\
\text { id }\end{array}$} & \multirow{2}{*}{$\begin{array}{l}\text { created } \\
\text { at }\end{array}$} & \multirow{2}{*}{$\begin{array}{l}\text { updated } \\
\text { at }\end{array}$} & \multirow{2}{*}{ im age } \\
\hline & & id & _id & & & & \\
\hline 152 & $\begin{array}{l}\text { 学会でお話を聞いて, 僕 } \\
\text { も欲しい場だと思いまし } \\
\text { た. また, 自分の地元に } \\
\text { 欲しいと思いました }\end{array}$ & 122 & 142 & NULL & $\begin{array}{l}2016 / 12 / 1 \\
6: 14: 57\end{array}$ & $\begin{array}{l}2016 / 12 / 1 \\
6: 14: 57\end{array}$ & NULL \\
\hline
\end{tabular}

議論機能を用いたコメント, および進捗報告の実例を 図 1, 図 2 に示す. 本研究では, 議論機能のユーザイン タフェース (以下, UI と記す) として, 電子掲示板型を 採用した。 進捗報告では任意のテキストと写真が投稿で きる設計とした。 


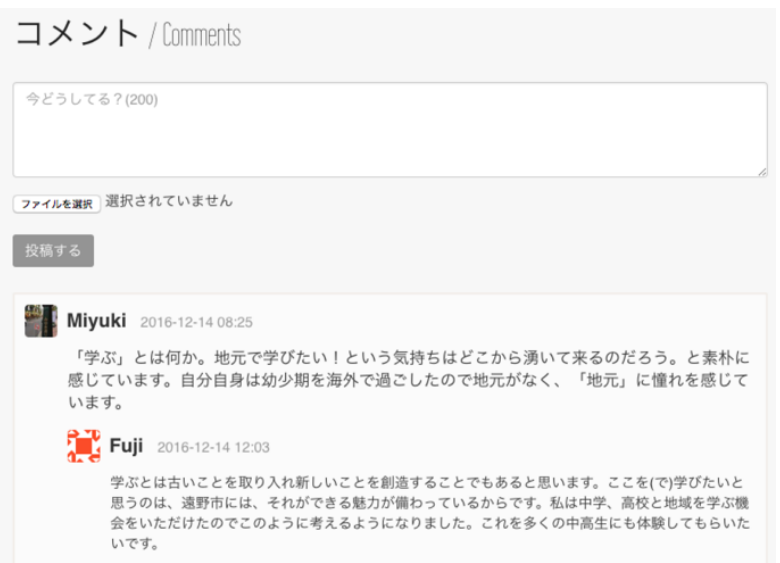

図 1 議論機能を用いたコメントの例

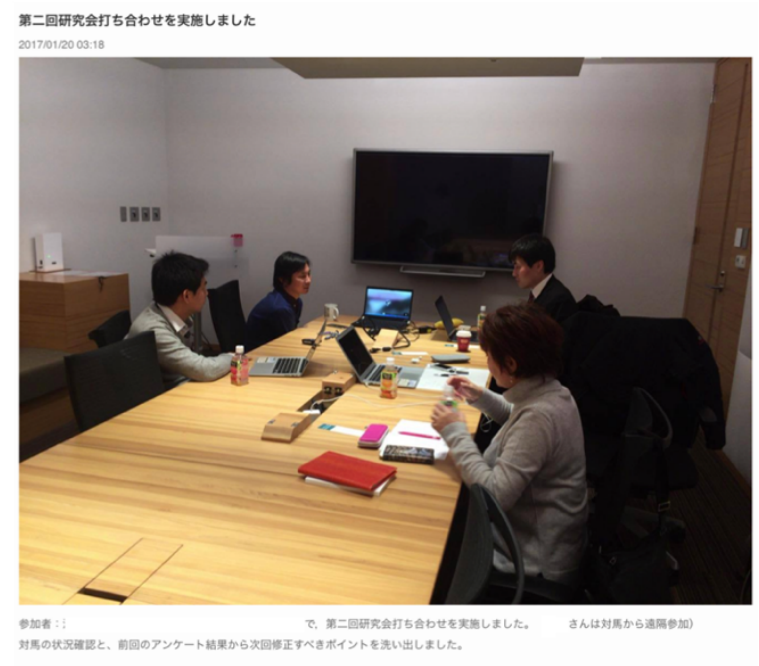

図 2 進捗報告機能を用いた投稿の例（個人名は削除済み）

\section{c. 共創活動によって創出された新たな成果}

共創活動によって創出された新たな成果を表 6 に示す。 共創プロジェクト活動によって創出された新たな成果が, 対外的にアウトプットされたときにカウントした。

\section{4 分析方法}

本研究会における成果は個人単位ではなくプロジェ クト単位で創出されるため, 分析対象のデータもプロジ エクト毎に集計したａに関しては，アンケート回答の 各設問の平均值をプロジェクト毎に算出した，b，cに関 しては，プロジェクト毎に合計值を算出した。

プロジェクト毎に集計したデータに対して， Spearman の順位相関係数を算出した。相関係数の算出 には，IBM SPSS Statistics 20®を用いた，有意確率は $5 \%$ に設定した。相関係数が有意だった項目を用いて，共 分散構造分析[狩野 02]によって成果数に影響を及ぼす 因果関係モデルを構築した。解析には IBM SPSS Amos $20 ®$ き用いた。有意確率は $5 \%$ に設定した。潜在変数を楕 円，観測変数を長方形で表した． 観測変数の右上の数值
表 6 共創活動によって創出された新たな成果

\begin{tabular}{|c|c|c|c|}
\hline プロジェクト名 & 種類 & 内容 & 成果数 \\
\hline \multirow{4}{*}{$\begin{array}{l}\text { スーパーアグリ } \\
\text { 構想 }\end{array}$} & \multirow{4}{*}{ 学会発表 } & $\begin{array}{l}\text { インタラクション2017[一ノ瀬 17a] } \\
\end{array}$ & \\
\hline & & 第79回情報処理学会全国大会[一ノ瀬 17b] & \\
\hline & & 第31回人工知能学会全国大会[一ノ瀬 17c] & \\
\hline & & 第2回市民共創知研究会 [一ノ瀬 $17 \mathrm{~d}]$ & \\
\hline \multirow{6}{*}{$\begin{array}{l}\text { 共創のための } \\
\text { 舞台をつくる }\end{array}$} & \multirow{3}{*}{ 学会発表 } & 第2回市民共創知研究会[池田 17a] & \\
\hline & & 第18 回日本オフィス学会[池田 17b] & \\
\hline & & 第 4 回市民共創知研究会[佐藤 18] & \\
\hline & \multirow{3}{*}{$\begin{array}{l}\text { イベント } \\
\text { 実施 }\end{array}$} & アカデミアと地域と企業を結びつける共創 & \\
\hline & & の場のつくりかた & \\
\hline & & 第2回市民共創知研究会の実施 & \\
\hline 遠野らしい学び & \multirow{2}{*}{ 学会発表 } & \multirow{2}{*}{ 第2回市民共創知研究会［遠山 17］ } & \multirow[t]{2}{*}{1} \\
\hline の場を創る & & & \\
\hline \multirow{2}{*}{$\begin{array}{l}\text { みらい創りの } \\
\text { 仲間づくり }\end{array}$} & \multirow{2}{*}{ 学会発表 } & 第2回市民共創知研究会[水谷 17a] & \multirow{2}{*}{2} \\
\hline & & 第3回市民共創知研究会 [水谷 $17 \mathrm{~b}$ ] & \\
\hline \multirow{2}{*}{$\begin{array}{l}\text { みんなでICTを } \\
\text { 楽しむ！ }\end{array}$} & \multirow{2}{*}{ 学会発表 } & 第3回市民共創知研究会[塚本 17] & \multirow{2}{*}{2} \\
\hline & & 第4回市民共創知研究会[塚本 18］ & \\
\hline
\end{tabular}

は重決定係数を, 矢印上の数值は標準偏回帰係数を示す. 「活動・関心の共有」はアンケート設問の Q2 を，「取り 組みたい共創活動の存在」は Q6 を示す.

\section{4. 結果}

プロジェクト毎の集計データを表 7 に示す. 各項目の Spearman の順位相関係数を表 8 に示す. 表 8 中の数值 に「*」がついている項目は両側有意，「**」がついてい る項目は片側有意を示す.

成果数と Q2 の間にやや高い正の相関 $(\rho=.617, \mathrm{p}<.05)$ 成果数と応援数 $(\rho=.764, \mathrm{p}<.01)$, コメント数 $(\rho=.901$, $\mathrm{p}<.01)$ との間に高い正の相関がみられた。またコメント 数と Q2 との間にやや高い正の相関 $(\rho=-.630, \mathrm{p}<.05)$, 応援数との間に高い正の相関 $(\rho=.720, \mathrm{p}<.05), \mathrm{Q} 6$ との 間に高い負の相関がみられた $(\rho=-.730, p<.05)$. 更に進 捗報告と $\mathrm{Q} 1(\rho=.763, \mathrm{p}<.01)$ ，参加者数 $(\rho=.716, \mathrm{p}<.05)$ との間に高い正の相関がみられた。

図 3 に共分散構造分析の結果を示す.複数のモデルを 比較した結果, 図 3 に示したモデルが最も適合性が高か った．図中の「*」は $5 \%$ 水準で有意,「**」は $1 \%$ 水準で 有意であることを示す。

共分散構造分析では，モデルの妥当性を適合性指標に よって評価する[小塩 14]. 本研究では, 適合性指標とし $\tau$, GFI(Goodness of Fit Index), AGFI(Adjusted Goodness of Fit Index), CFI(Comparative Fit Index), RMSEA(Root Mean Square Error of Approximation)の 4 つを用いた。 GFI は，データの分散共分散をモデルが どの程度説明するかを示す指標である．０から 1 までの 值を取り，0.9 以上が望ましいとされる。AGFI は GFI の自由度調整済み指標である. AGFI が GFI と比較して 著しく低下するモデルは望ましくないとされる. CFI は, 各観測変数が無相関であることを仮定した独立モデルと 比較して，適合度がどれほど改善されたかでモデルを評 
表 7 プロジェクト毎の集計データ

\begin{tabular}{|c|c|c|c|c|c|c|c|c|c|c|c|c|c|c|c|}
\hline \multirow[b]{2}{*}{ 研究会 } & \multirow[b]{2}{*}{ プロジェクト名 } & \multicolumn{9}{|c|}{ 1.アンケート } & \multicolumn{4}{|c|}{ 2.ログデータ } & \multirow{2}{*}{$\begin{array}{l}\text { 3.成果数 } \\
\text { 成果数 }\end{array}$} \\
\hline & & Q 1 & Q2 & Q3 & Q 4 & Q5 & Q 6 & Q7 & Q 8 & Q9 & $\begin{array}{l}\text { 参加 } \\
\text { 者数 }\end{array}$ & $\begin{array}{l}\text { 応援 } \\
\text { 数 }\end{array}$ & $\begin{array}{l}\text { コメン } \\
\text { ト数 }\end{array}$ & $\begin{array}{l}\text { 進捗 } \\
\text { 報告数 }\end{array}$ & \\
\hline \multirow{5}{*}{ 第1回 } & "スーパーアグリ構想 & 4.83 & 5.50 & 5.17 & 4.83 & 5.33 & 1.00 & 1.33 & 5.17 & 1.33 & 8 & 8 & 65 & 1 & 4 \\
\hline & みらい創りの仲間づくり & 5.25 & 5.50 & 5.25 & 5.25 & 5.50 & 1.00 & 1.00 & 5.25 & 1.00 & 6 & 10 & 14 & 2 & 2 \\
\hline & 遠野らしい学びの場を創る & 5.00 & 5.40 & 5.20 & 4.60 & 5.20 & 1.00 & 1.00 & 4.80 & 1.40 & 6 & 13 & 17 & 0 & 1 \\
\hline & $\begin{array}{l}\text { 共創のための舞台をつくる } \\
\text { ～次回研究会に向けて〜 }\end{array}$ & 5.50 & 5.75 & 5.00 & 5.50 & 6.00 & 1.00 & 1.25 & 5.75 & 1.00 & 8 & 13 & 81 & 11 & 5 \\
\hline & $\begin{array}{l}\text { 新しい働き方をレシピ形式で } \\
\text { 集約する方法の提案 }\end{array}$ & 5.00 & 5.40 & 5.60 & 5.20 & 5.60 & 1.20 & 1.60 & 5.40 & 1.00 & 5 & 5 & 4 & 0 & 0 \\
\hline \multirow{4}{*}{ 第2回 } & $\begin{array}{l}\mathrm{AI} x \text { 対馬 : } \mathrm{AI} \text { で日本史を } \\
\text { 書き換える！ }\end{array}$ & 5.50 & 5.00 & 5.50 & 5.25 & 5.50 & 1.00 & 1.00 & 5.50 & 1.00 & 7 & 1 & 6 & 6 & 0 \\
\hline & みんなでICTを楽しむ！ & 5.00 & 4.00 & 5.00 & 4.00 & 4.00 & 1.00 & 1.00 & 4.00 & 1.00 & 6 & 11 & 10 & 5 & 2 \\
\hline & 井戸端リテラシー向上委員会 & 5.25 & 5.25 & 5.00 & 4.75 & 5.00 & 1.25 & 1.50 & 4.75 & 1.00 & 7 & 3 & 3 & 6 & 0 \\
\hline & $\begin{array}{l}\text { 学びとものづくり空間 } \\
\text { 「TSUSHIMA DESIGN」設立 }\end{array}$ & 5.00 & 4.50 & 5.00 & 5.00 & 5.00 & 1.00 & 1.00 & 5.00 & 1.00 & 4 & 2 & 5 & 0 & 0 \\
\hline
\end{tabular}

\section{表 8 Spearman の順位相関係数}

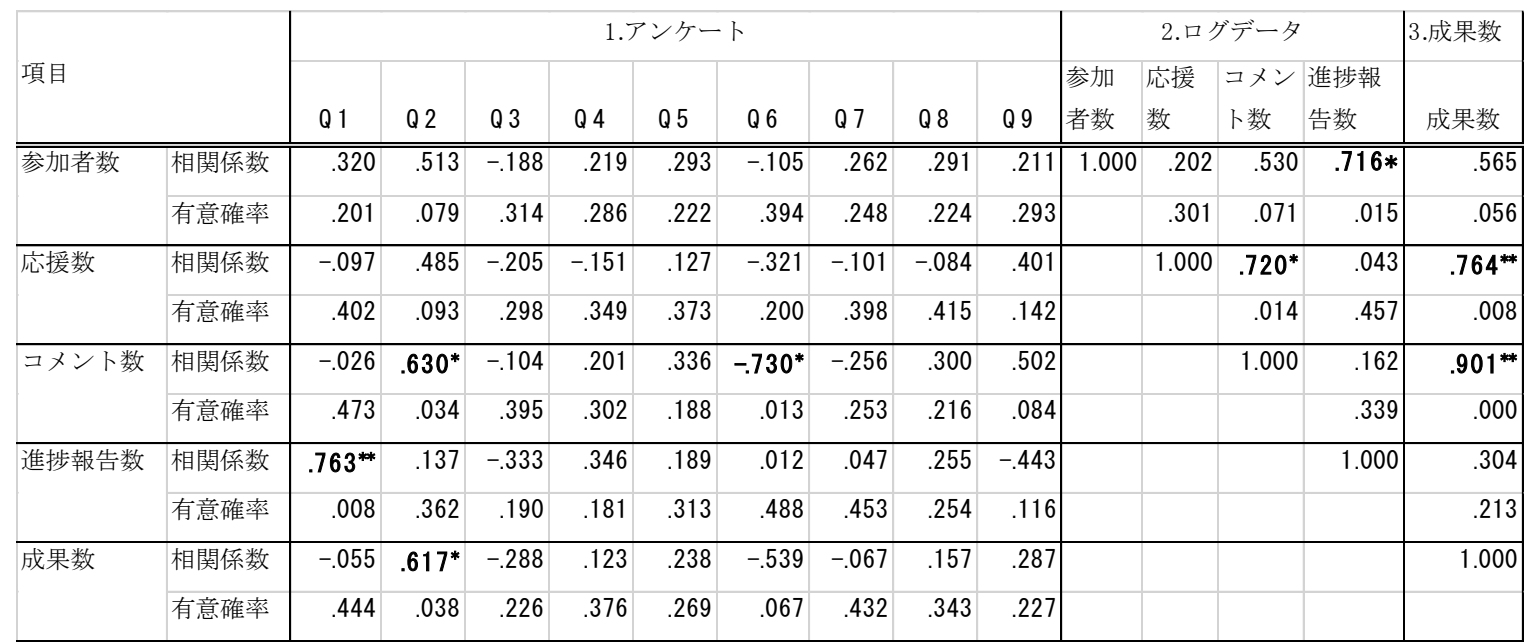

価する指標である。 0 から 1 までの值をとり，1に近いほ ど適合が良いとされる. RMSEA は, モデルの分布と真の 分布との乘離を, 1 自由度あたりの量として表現した指標 である. 0.05 以下であれば適合が良いとされる。

図 3 に示したモデルの適合性指標の值は, GFI=.96, $\mathrm{AGFI}=.81, \mathrm{CFI}=1.00, \mathrm{RMSEA}=.00$ であった。 パス係数

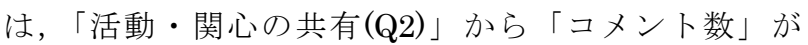
$0.57(\mathrm{p}=.018)$, 「取り組みたい共創活動の存在 $(\mathrm{Q} 6$, ある場 合は值が低い)」から「コメント数」が-0.45(p=.060),「コ

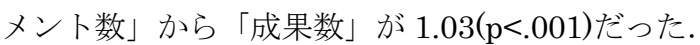

コメント数と成果数との相関について, 両者に影響する 共通要因が存在する疑似相関の可能性も考えられる. そこ で, コメント数と成果数の双方に影響する潜在変数の存在 を仮定したモデルを作成し, 共分散構造分析の結果を図 3 に示したモデルと比較した. 比較の指標には赤池情報量基 準(Akaike’s Information Criterion: AIC)を採用した. AIC は複数のモデルの相対的な良さを比較するための指標で あり，值が低いモデルを選択する[小塩 14]. その結果，

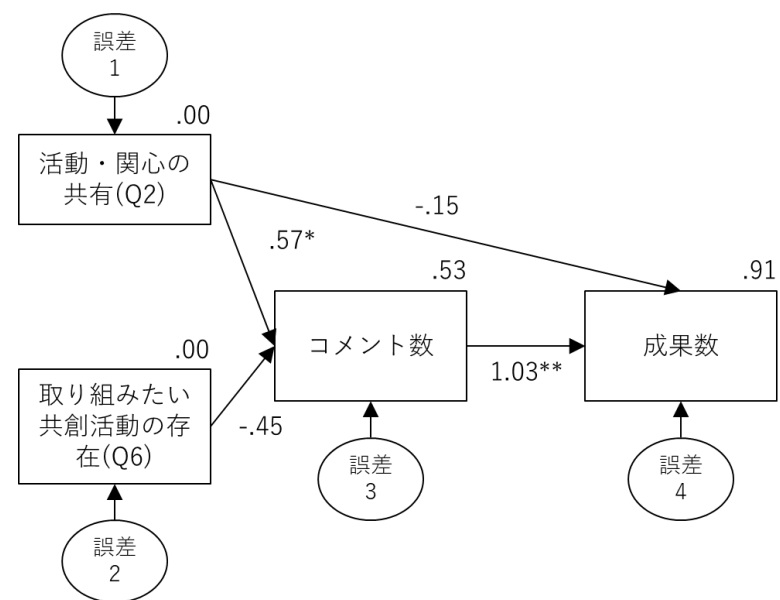

図 3 共分散構造分析結果

図 3 に示したモデルでは $\mathrm{AIC}=16.66$, 潜在変数の存在を 仮定したモデルでは $\mathrm{AIC}=18.24$ となり, 図 3 に示したモ デルがより適切という結果になった。 


\section{5. 考察}

\section{$5 \cdot 1$ 仮説 1 について}

他の参加者の活動や関心を知ることができたかを尋叔 た Q2 と, コメント数, 成果数との間に正の相関がみられ た. 仮説 1 に関して, 研究会の「他の参加者の活動や関心 を知る」という狙いの達成度が高いほど, ユーザ行動数が 増加することが示された. 研究会における対話 WS 時に, 参加者間の情報交換や交流の機会を増加させ, 活動や関心 の共有を促進することが，コメント数を増加させることが 示唆される.

また Q6 とコメント数との間に高い負の相関がみられた. この結果は, 取り組みたい共創プロジェクトが存在するほ ぞ，コメント数が増加すると解釈できる. 共創活動に対す る内発的動機づけが, ソーシャルメディア上のコメント数 を増加させることが示唆される. しかし Q6 は他の項目と 相関がみられなかった. 共創活動に対寸る内発的動機づけ を促進する要因について調查することで,ソーシャルメデ イア上のコメント数を増加させられる可能性がある.

Q3，4，5，7 とユーザ行動数や成果数との間には有意な 相関はみられなかった。 以降で設問毎に理由を考察する.

Q3 に関して, 全プロジェクトの回答の平均值が 6 段階 中 5 以上だったことが理由として挙げられる. 回答結果に 大きな偏りがみられるため, 質問内容が適切でない可能性 が示唆される、Q3 は他の参加者之関係性を築けたかに関 する質問だが，「関係性」という言葉は広い意味を持つた め, より範囲を絞った具体的な質問に修正する等の対応を 検討する必要がある.

Q4 に関して, 全プロジェクトで回答の平均值は 4 以上 だったが, ユーザ行動との関係には有意な相関はみられな かった. 理由として, 得られた共創アイデアを具体的な計 画や行動に落とし込めていないこと等が挙げられる. 対話 WS 中, またはソーシャルメディア上で具体的な計画や行 動に落とし込むことを促すことによって, 共創アイデアを 実際の行動につなげられる可能性がある.

Q5 に関して, 多くの共創プロジェクトでアンケート回 答の平均值は 5 以上だったが, ユーザ行動数にはばらつき がみられた. 理由として, 共創プロジェクト活動を何から 始めてよいかわからない, 活動のきっかけが掴めない等が 考えられる. 前者の対策としては, ソーシャルメディア上 に活動のチュートリアルを用意する, ユーザ行動数が多い 共創プロジェクトの活動の進め方を参考にしてもらう等 が考えられる. 後者の対策としては, 研究会後に一定期間 ユーザ行動がみられない参加者に対して, ソーシャルメデ イア上で何らかのユーザ行動を行うことを促す等が挙げ られる.このような対策を講じることで, 研究会後のユー ザ行動を促進できる可能性がある.

Q7 に関して, 研究会後の共創活動の予定の有無とユー ザ行動数との間に相関がみられなかった理由として, 研究
会中に今後の予定が決まらなくても,ソーシャルメディア 上で検討を行えたことが挙げられる. 対話 WS のみの設 計だった場合は, 対話 WS 中に次回の活動予定を決めな いと，次の活動に移ることが難しいことが予想される．し かし本研究では, 研究会後にソーシャルメディア上で活動 を行えることが事前に参加者に告知され, 実際に研究会直 後から活用が進んだ. 本研究のように, 対話 WS とソーシ ヤルメディアを組み合わせた共創では, 対話 WS 中の限 られた時間の中で㳄回の活動予定を決めることに時間を 費や寸のではなく，Q6 でみられるように参加者が取り組 みたいと思える共創プロジェクトを練り上げることに注 力したほうが, ユーザ行動の促進につながる可能性がある.

\section{$5 \cdot 2$ 仮説 2 について}

参加者数と進捗報告数, 応援数とコメント数・成果数と の間に高い正の相関がみられた. 参加者数と進捗報告数と の相関に関して, 多くの参加者がプロジェクトに参加した ことが, ユーザの活動や進捗報告に対する動機づけになっ た可能性がある.一方, 参加者数とコメント数との相関は みられなかったため, 参加者全員によってコメントが投稿 されたというよりは, 一部のユーザによって活動が進めら れた結果が報告されたと推測される、今後は進捗報告を行 ったユーザの行動を分析し, 結果に応じた支援方法を模索 する必要がある.

後者の応援数とコメント数・成果数との相関に関して, 他ユーザからの応援という肯定的なフィードバックが, コ メント数・成果数の増加を促進したことが示唆される. 応 援機能はプロジェクト作成という特定のユーザ行動に対 する肯定的なフィードバックであるが，ユーザ行動には， 他にもコメント，進捗報告等が存在する. これらのユーザ 行動に応じた肯定的なフィードバック機能を設けること で, コメント数をはじめとしたユーザ行動数や成果数を更 に増加させられる可能性がある。

\section{$5 \cdot 3$ 仮説 3 について}

コメント数と成果数との間に高い正の相関がみられた. この結果は, コメントといらユーザ行動の数が多いほど, 成果数が増加することを示している.この結果に対しては, 以下の 2 つの解䣋が可能である. 1 つ目は, ソーシャルメ ディア上のコメントが増加したことによって, 共創プロジ エクト活動が進み, 成果が創出されたという解釈である. この場合は, 議論機能のユーザビリティの見直しによる議 論のしやすさの向上や, 議論の活性化を支援する機能の導 入によって, 成果数の増加に寄与できると考えられる. 2 つ目は, あるユーザのコメントに対する他のユーザからの 返信が, 最初にコメントしたユーザに対するフィードバッ クになり，活動に対する動機づけが行われた結果，活動が 進み成果につながったといら解釈である。つまり, 仮説 2 と同様, あるユーザのコメントに対する他のユーザの返信 がフィードバックとして機能し, 活動の動機づけになった という解釈である。 この場合は, より簡易にフィードバッ クが可能な機能の追加や, ゲーミフィケーションによるユ 
ーザ行動の動機づけによって, 更に成果数を増加させられ る可能性がある.今後コメント数と成果数が高い相関をも つ理由の特定を行い, 成果数を増加させるために必要な支 援機能を実装する必要がある.

コメント数と成果数との間に高い正の相関がみられた 別の理由として, ソーシャルメディアの議論機能の UI や 通知機能の設定が考えられる. まずUIに関して, 議論が 可能な UI としてチャット型や電子掲示板型等の選択肢が 存在するが, 本研究では図 1 に示した電子掲示板型を採 用した。電子掲示板型を採用することのメリットとして, スレッドごとに議論が構造化されるため, チャット型と比 較してユーザが議論内容を効率的に理解することが可能 であることが挙げられる. 議論内容を効率的に把握でき議 論に参加しやすくなったことが, コメント数と成果数との 相関に正の影響を与えた可能性がある. 次に通知機能につ いて, 本研究では, ユーザによるコメントがつけられた直 後に, プロジェクト参加者に対してメールで通知が届く設 定とした. そのためプロジェクト参加者は, ソーシャルメ ディアを見ていなくてもコメントがついたことを把握で き, 必要に応じてコメントに対する反応を迅速に行うこと が可能になった.このことが, 共創プロジェクト活動に関 するインタラクションの効率化や, 停滞の防止等の効果が あった可能性がある. 今後はコメント数と成果数との間に 高い正の相関があった要因を, ソーシャルメディアの設計 上の観点から更に追及することが望まれる.

一方, コメントの内容がコメント数と成果数との相関に 影響を及ぼした可能性もある. 本研究と同じデータ*1を用 いてコメント内容のコーディングを行った研究[堀田 19b]では, 全コメントの 52.8\%が活動推進に関わる「推進」, $22.3 \%$ が活動に関する知識の授受や他ユーザへの質問・回 答等の「知識の授受」, $24.9 \%$ が他ユーザのコメントに関す る感想, 他ユーザに対する御礼, プロジェクト以外のイベ ントや活動への勧誘等の「その他」に分類された.この結 果から, 多くのコメントが共創プロジェクトを推進するた めのコメントや, 他ユーザとの知識のやり取りだったこと が読み取れる. 進捗報告に関しても同様の傾向がみられた. 多くのコメントや進捗報告が共創プロジェクトを進める 上で建設的な内容だったことが, 本研究の結果に影響を与 えた可能性がある. 逆に建設的なコメントや進捗報告が少 ない場合は, 本研究とは異なる影響がみられる可能性があ る.コメントや進捗報告の内容とコメント数・成果数との 関連について, 今後更なる分析が行われることが望まれる. 進捗報告数と成果数との間には相関はみられなかった。 理由として, 以下の 2 点が考えられる. 1 点目は, 堀田[堀 田 19b]でも指摘されていたように，プロジェクトの活動 報告が, 進捗報告機能ではなく, 議論機能を通して行われ ていた可能性がある. 両者の違いは通知の範囲にある. 議

*1 本研究と[堀田 19b]ではデータ取得期間は異なるが，分析対 象とした共創プロジェクトに関しては追加データがなかったた
論機能は同プロジェクトに参加したユーザにのみ通知が 行われるが, 進捗報告機能はソーシャルメディアのユーザ 全員に通知が行われる。そのため, 全員に通知するほど大 きな進捗がない場合は, 進捗報告機能ではなく議論機能を 用いて活動報告が行われた可能性がある．2 点目は，進捗 があっても報告されない場合がある. 報告する必要性や, 時間的・人的リソースの不足等が理由として考えられる. しかし根本[根本 14 ] も指摘しているように, 他者行動の 共有がプロジェクトに関する行動を喚起する可能性も示 唆される.ソーシャルメディア側が進捗の有無を自動で判 断し, 進捗があった場合は他ユーザに報告する等の機能を 導入すれば, ユーザに負担をかけることなく進捗報告を行 うことができ, 更なるユーザ行動を喚起できる可能性があ る.

\section{$5 \cdot 4$ 共分散構造分析について}

図 3 に示したモデルは，適合性指標の基準をある程度

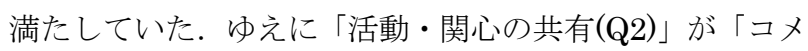
ント数」に有意に影響し，「コメント数」が「成果数」に 有意に影響するという因果関係モデルに, 一定の妥当性が あることが示唆された．また $5 \%$ 水準では有意ではなかっ たが，「取り組みたい共創活動の存在(Q6)」もコメント数 に影響を及ぼす可能性が示唆された.

本モデルによって共創支援の対象が示されたことで, 成 果数を増加させる支援方法を具体的に検討できると考え られる。例えば，発表・対話の場面では交流機会の増加や 多様な交流方法の導入によって, 共創プロジェクトを作る 場面ではオーナーの目標・ビジョンの共有によって, 参加 者間の活動・関心の共有を促進し，コメント数の増加を支 援できる可能性がある. 加えて共創活動の実践では, ソー シャルメディアに議論活性化機能等を付与しコメント数 を増加させることが, 成果数の増加につながる可能性があ る.

\section{$5 \cdot 5$ 本研究の限界}

本研究の限界を, ソーシャルメディアのログを用いた分 析, 成果の指標という 2 つの観点から記述する.

前者に関して, 本研究では専用のソーシャルメディアの ログを用いた分析を実施したが, 本ソーシャルメディア以 外で発生した対面またはオンライン上の会話・行動等のデ 一夕は取得できなかった。 またこれらの会話・行動以外に も, 共創プロジェクト活動を促進する要因として, 参加者 および共創プロジェクトの特性，参加者間の関係，共創活 動に対するリソースの有無等多様な観点が考えられるが, これらの観点に関しても本研究では扱えなかった.今後は ケーススタディやインタビュー等の手法を用いた共創プ ロジェクト活動の比較・分析を通じて, 上記の観点を含め た成果創出に寄与する要因を更に明らかにすることが望 まれる。

め，ログデータの内容は同一である. 
後者に関して, 本研究で分析対象とした成果は, 最終目 標である地域課題解決に向けた中間指標を含んでいた. 本 研究で創出された成果には学会発表やイベント実施が含 まれたが, 本来はこれらの成果を更に発展させた結果, 地 域課題解決が促進されることが望まれる，そのためには, 更なる成果を生むための活動の長期化に耐えうる支援が 望まれる. 白松は, 学術機関で長期間研究を継続するには, 研究資金獲得と人材育成が不可欠であると指摘した[白松 19]. この指摘は本研究の対象である共創プロジェクト活 動にも当てはまると考える，活動資金の獲得については, 補助金・助成金・科研費等の外部資金の獲得や，クラウド ファンディング[Readyfor 11]の活用等が有効であると考 えられる.人材育成に関しては, 研究室の学生や地域おこ し協力隊のような, 共創プロジェクトに関わることが本人 の成果にもつながる人々を巻き込むことが, 教育と共創プ ロジェクト活動を両立する上で有効である可能性がある. これらの資金・人材に関する支援を実施することで, 最終 目標である地域課題解決に寄与できる成果を創出できる 可能性がある. 最終的に創出された成果の評価指標として は, Social Return on Investment（以下, SROI と記す） 等の指標が有効であると考える. SROI は，事業への投資 価值の評価を, 金銭的価值だけでなくより広い価值の概念 に基づいて行うためのフレームワークである [Social Value Japan 19]. 共創プロジェクトで創出される成果は, 金銭的価值以外の社会的価值を多く含むため, SROI 等の 指標を用いて評価することが望ましいと考える.

\section{6. まとめ}

本研究の目的は, 共創活動を通じた新たな成果の創出を 促進する要因を検証することだった. 既存研究から導出し た仮説として，1.対話 WS の狙いの達成度が高いほど， ユーザ行動数が増加する, 2.ユーザ行動に対するフィード バックが多いほど, ユーザ行動数が増加する，3.ユーザ行 動数が多いほど, 成果数が増加する, という3つを挙げた。 研究対象は市民共創知研究会とした. 分析対象のデータ として, a.研究会後に実施されたアンケートの回答, b.ソ ーシャルメディアのログデータ, c. 共創活動によって創出 された新たな成果を抽出した. a から $\mathrm{c}$ の各データをプロ ジェクト毎に集計し，有意確率を $5 \%$ に設定して Spearman の順位相関係数を算出した. 相関係数が有意だ った項目を用いて, 共分散構造分析によって成果数に影響 を及ぼす因果関係モデルを構築した。

本研究によって得られた主な知見を, 以下にまとめる.

1. 研究会において他の参加者の活動や関心の共有を促 進することは, ソーシャルメディア上のコメント数や, 創出される成果数を増加させる可能性が示された.

2. 共創プロジェクトに対する応援数を増加させること が, ソーシャルメディア上のコメント数の増加, およ び創出される成果数の増加に寄与寸ることが示唆さ
れた.

3. ソーシャルメディア上のコメント数の増加を支援す ることが, 創出される成果数を増加させる可能性があ ることを確認できた.

4. 共分散構造分析によって構築した, 成果数に影響を及 ぼす因果関係モデルに, 一定の妥当性があることを確 認した.

本研究の新規性は, 研究者と市民との共創活動における 成果の創出を促進する要因を検証したことである. 本研究 で得られた知見により，市民との共創活動における成果創 出のために必要な人や人工知能による支援方法を, 具体的 に検討できるようになると考える.

一方, 本研究で得られたデータは 9 個の共創プロジェク トで得られた限定的なものであった，そのため，分析の枠 組みや結果の一部は示せたが, 得られた結果が一般化でき るとは現時点では言い切れない. 今後研究対象を広げ, デ 一タの母数を増やした上で検証を継続したい.

\section{謝辞}

市民共創知研究会にご参加いただいた皆様に, 心より感 謝申し上げます。本研究内容は, JST CREST「エージェ ント技術に基づく大規模合意形成支援システムの創成: 代 表伊藤孝行」(グラント番号 JPMJCR15E1)に支援を受け ている研究の一部である.

付記 SPSS は, インターナショナル・ビジネス・マシ ーンズ・コーポレーションの登録商標である.

\section{$\diamond$ 参考文献 $\diamond$}

[赤坂 17] 赤坂文弥，木村篤信：リビングラボの方法論的特徵の 分析,日本デザイン学会第 64 回春季研究発表大会概要集, B1-05, pp. 22-23 (2017)

[Bergvall-Kåreborn 09] B. Bergvall-Kåreborn, and A. Ståhlbröst,: Living lab: an open and citizen-centric approach for innovation. International Journal of Innovation and Regional Development, Vol. 1, No. 4, pp. 356-370 (2009)

[ENoLL 06] ENoLL.: The European Network of Living Labs. https://enoll.org/about-us/ (2006) (参照 2021-06-06)

[堀田 19a] 堀田竜士, 三井実, 伊藤孝行, 白松俊, 藤田桂英, 福田直樹：研究者と市民の共創を生み出す研究会の提案, 人工知能, 第 34 巻, 4 号, pp. D-I92_1-8 (2019)

[堀田 19b] 堀田竜士, 仙石晃久, 伊藤孝行: 多地域移動型の共創 を支援するソーシャルメディアシステムの試作と評価，人 工知能, 第 34 巻, 2 号, pp. F-I57_1-8 (2019)

[一ノ瀬 17a] 一ノ瀬修吾, 白松俊, 大森友子: Kinect を用いた 鍬動作の比較分析のための動作プリミティブ分割機構の試 作，インタラクション 2017, 3-410-64 (2017)

[一ノ瀬 $17 \mathrm{~b}$ ] 一八瀬修吾, 白松俊, 大森友子：市民共創による農 作業支援技術開発のためのモーションセンサを用いた鍬動 作の分析, 第 79 回情報処理学会全国大会, 6D-06 (2017)

[一ノ瀬 17c] 一八瀬修吾, 白松俊, 大森友子: Kinectを用いた鍬 動作の初心者と熟練者の比較分析手法の試作, 第 31 回人 工知能学会全国大会, 2E4-OS-36b-3in1 (2017) 
[一ノ瀬 17d] 一八瀬修吾, 白松俊, 大森友子: Kinectを用いた鍬 動作分析研究における市民共創知研究会を通じた今後の展 望, 第 2 回市民共創知研究会 (2017)

[池田 17a] 池田晃一：共創をうながす柔軟なはたらき方の検証, 第 2 回市民共創知研究会 (2017)

[池田 17b] 池田晃一：共創の場の設計とそれを支えるプラット フォームについて, 第 18 回日本オフィス学会 (2017)

[井上 16] 井上絵里, 中島円, 庄司昌彦, 野村恭彦, 筧大日蛹 朗，野本紀子，神武直彦：オープンデータを利用して集合 知によって地域課題の発見から解決までを支援するシステ ム -川崎市での G 空間未来デザインプロジェクトを例に情報処理学会デジタルプラクティス, Vol. 7, No. 2, pp. 148-157 (2016)

[伊藤 17] 伊藤孝行, 仙石晃久, 白松俊, 藤田桂英, 三井実, 堀田 竜士，福田直樹：市民共創知研究会の構想：グローバルで 持続可能な地域創生活動支援の仕組み, 2017 年度人工知能 学会全国大会（第 31 回）（2017）

[狩野 02] 狩野裕：共分散構造分析の基礎と実際－基礎編一, SSJ データ・アーカイブ第 6 回公開セミナー 社会調査の 2 次分析シリーズ 第 1 回 (2002)

[香取 11] 香取一昭，大川恒：ホールシステム・アプローチー 1000 人以上でもとことん話し合える方法, プレジデント 社 (2011)

[古崎 16] 古崎晃司，上田洋，高橋徹：シビックテックと LOD 関西での活動を中心として-，情報処理，57 巻， 7 号, pp. 620-625 (2016)

[野村 12] 野村恭彦：フューチャーセンターをつくろう一対話 をイノベーションにつなげる仕組み，プレジデント社 (2012)

[水谷 17a] 水谷美由起：「チームみらい創り」, 始まります. 複 数みらい創り拠点間市民協働を目的とした遠隔対話実験の 実施，第 2 回市民共創知研究会 (2017)

[水谷 $17 \mathrm{~b}$ ] 水谷美由起, 尾崎夏穂, 千葉祥子, 山口昌美：複数み らい創り拠点間市民協働を目的とした遠隔対話実験結果の 検討，第 3 回市民共創知研究会 (2017)

[根本 14] 根本啓一, 高橋正道, 林直樹, 水谷美由起, 堀田竜 土，井上明人：ゲーミフィケーションを活用した自発的・ 持続的行動支援プラットフォームの試作と実践，情報処理 学会論文誌, Vol. 55, No. 6, pp. 1600-1613 (2014)

[大西 17] 大西翔太，小林重人，橋本敬：日本国内のシビックテ ックにおける技術者と非技術者の協働促進に関する研究, 地域活性学会研究大会論文集, 9 巻, pp. 26-29 (2017)

[小塩 14] 小塩真司：はじめての共分散構造分析 Amosによる パス解析第 2 版，東京図書 (2014)

[オーエン 07] ハリソン・オーエン: オープン・スペース・テク ノロジー〜 5 人から 1000 人が輪になって考えるファシリ テーション〜，ヒューマンバリュー (2007)

[Readyfor 11] Readyfor: はじめてのクラウドファンディング, https://readyfor.jp/crowdfunding/ (2011) (参照 2021-06 12)

[佐藤 18] 佐藤雄二:「みらいらぼつしま」開催から考える地域 型コンベンションの可能性，第 4 回市民共創知研究会 (2018)

[瀬戸 16] 瀬戸寿一，関本義秀：地理空間情報のオープンデータ 化と活用を通した地域課題解決の試み〜「アーバンデー タチャレンジ」を事例に〜，映像情報メディア学会誌, 70 巻, 11 号, pp. 840-846 (2016)

[白松 19] 白松俊, 伊藤孝行, 福田直樹, 堀田竜士, 三井実, 藤 田桂英：市民共創知研究会 (CCI)：地域課題に立ち向かう知 を $\mathrm{AI}$ 研究者と市民が共創する場，人工知能，第 34 巻， 5 号, pp. 616-621 (2019)

[Social Value Japan 19] Social Value Japan: SROI 入門, http://socialvaluejp.org/wp-
content/uploads/2018/08/SROI\%E5\%85\%A5\%E9\%96\%80 Social-Value-Japan.pdf, (2019) (参照 2021-06-12)

[高橋 15] 高橋正道, 涌井美帆子, 堀田竜士, 林直樹, 河野克 典: コンタクティビティ-岩手県遠野市における持続的な地 域共創活動を支援・促進する方法のケーススタディー，電 子情報通信学会 信学技報, Vol. 114, No. 517, pp. 1-6 (2015)

[遠山 17] 遠山竜也，伊藤孝行：第 1 回市民共創知研究会にお ける実例に基づいた研究会に高校生が参加寸る意義と留意 点に関する考察，第 2 回市民共創知研究会 (2017)

[塚本 17] 塚本初恵: Minecraft や micro:bit を活用した居場所作 り〜一人一人のいいところを発見しあう〜，第 3 回市民 共創知研究会 $(2017)$

[塚本 18] 塚本初恵: ICT 情報工房における子供向けプログラミ ング教育，第 4 回市民共創知研究会 (2018)

[宇賀田 17] 宇賀田栄次，佐藤直樹，天野 浩史：気づきとアク ションを生み出すフューチャーセンターのセッション設 計：しずおか消費者教育未来会議を事例として, 静岡大学 生涯学習教育研究, (19), pp. 15-25 (2017)

[涌井 15] 涌井美帆子, 三井実：対話×オンラインコラボレーシ ヨンー対話から持続的な活動を生み出すプロセスの検証-, 情報処理学会研究報告, Vol.2015-GN-96, No.20 (2015)

〔担当委員：芦川将之〕

2020 年 10 月 5 日 受理

\section{著 者 紹 介—}

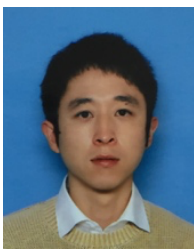

堀田 竜士

2011 年東北大学大学院工学研究科都市・建築学 専攻修了．同年，富士ゼロックス株式会社（現 富士フイルムビジネスイノベーション株式会 社) に入社. 2020 年名古屋工業大学大学院工学 研究科情報工学専攻博士後期課程修了.博士(工 学). 本学会第 2 種研究会市民共創知研究会幹 事. 2017 年 KICSS 2017 The Kunifuji Award, 同 Best Paper Award, 2019 年情報処理学会グループウェアとネットワークサービスワ ークショップベストペーパー賞.

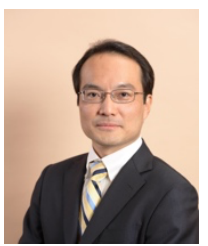

伊藤 孝行 (正会員)

京都大学大学院情報学研究科社会情報学専攻 教授. 博士(工学). 北陸先端科学技術大学院大 学・名古屋工業大学准教授, 内閣府最先端・次 世代研究開発プロジェクトPI，JST さきがけ研 究員・CREST 代表研究者. USC, ハーバード, MIT, 東京大学客員研究員, 名古屋工業大学教 授を経て， 2020 年より現職. JSAI 功績賞，JSAI 業績賞，ITS シ ンポ最優秀論文賞, JSSST 基礎研究賞, JSPS 賞, 文部科学大臣表 彰科学技術賞, 文科大臣表彰若手科学者賞, IPSJ 長尾真記念特別 賞，JSSST 論文賞受賞. AAMAS2013 PC Chair. IFAAMAS 国際財 団理事. 